\title{
Robert Kilwardby on the Relation of Virtue to $\mathrm{H}$ appiness
}

\author{
ANTHONY J. CELANO \\ Stonehill College
}

The growing sophistication of philosophical speculation together with the increasingly contentious claims of the thirteenth-century masters of Artsand Theology is reflected in the literary career of Robert Kilwardby. As a young Parisian Arts master, Kilwardby devoted much of his energy to explaining the works of Aristotle, recently introduced into the University's curriculum. Although particularly interested in the logical treatises, Kilwardby most likely commented upon the so-called 'Ethica vetus et nova', which were part of the Arts curriculum in the first half of the thirteenth century. Kilwardby's commentary, while quicklysuperseded by the more complicated questionson the entire Ethics, represents an extremely important transitional phase in the understanding of Aristotle's moral philosophy. Kilwardby's careful reading of Aristotle's text allowed him to reject the usual religious interpretation of his contemporaries. $\mathrm{H}$ is awareness of the limitations of moral science marks a decisive step away from the earlier reading of the Nicomachean Ethics (EN), which viewed Aristotle's doctrine of the human good to be identical with the religiousideal of union with God. Asa result, Kilwardby's commentaryon the EN demonstrated how Aristotle's ethics could no longer be understood as a slight variant of Christian moral theology.

The commentary on the Ethica vetus and nova, ascribed to Robert Kilwardby, is preserved in two manuscripts: Cambridge Peterhouse Library, 206 (C) and Prague University Library, III. F. 10 (Pr). The second manuscript contains only the commentary on the Ethica nova, that is, the first book of Aristotle's N icomachean Ethics. ${ }^{1}$ The work itself reflects the teaching activity of a Parisian Arts master shortly before the appearance of the entire text of the $\mathrm{EN}$ in the Latin West. The commentaryisundoubtedlyan introduction to the

This article is a revised version of a presentation at the Thomas-Institut in Cologne on M ay 6, 1998. I would like to thank Professors Jan Aertsen and Andreas Speer for their kind invitation, and all the participants for their helpful comments. I would also like to thank the Fulbright Commission for making possible my research activities in Germany in 1998.

1. P. O. Lewry, "Robert Kilwardby's Commentary on the Ethica nova and vetus" in L'homme et son univers au moyen âge, ed. C. Wenin (Philosophes méd. 26-27, Louvain-la-N euve, 1986), II:799-807. 
moral philosophy of Aristotle, since its author is content simply to explain clearly and thoroughly the words of Aristotle and ignores the method of 'qu estion es', which arise from the text. Even in thisearly phase of the reception of Aristotle at the University of Paris questions were considered a useful manner of instruction, as can be seen in the other commentaries on the Ethics from thisperiod. ${ }^{2}$ Kilward by'stext, although elementary, representsan early, but ver yimportant, stage in the medieval reception of Aristotle'sEthics, especially because the commentator understands the Greek notions of happiness and virtue to be different from the Christian ideals of perfect beatitude and the theological virtues. $\mathrm{H}$ is clear separation of the realms of rational philosophy and moral theology represent an important element in the understan ding of the nature of Aristotle'sE thics in the thirteenth century.

The ascription of the commentary to Robert Kilwardby is supported by neither Trevet's catalogue of Kilwardby's works, nor the so-called Stamms Catalogue of Dominican writers. Although the manuscripts do not attribute the work to Kilwardby, a fourteenth-century flyleaf in C ascribes the work to him. Although such later ascriptions are notoriously unreliable, the doctrine, style, and citations to other works are similar to authentic works of Kilwardby. Although the question of the authenticity of the commentary cannot be determined with certainty, this work is likely the product of Kilwardby's teaching activity at Paris prior to entering the Dominican O rder. ${ }^{3}$

Kilwardby understands the division of philosophical sciences in a manner far different from the traditional Aristotelian categorization into speculative, practical, and mechanical learning. 4 Especially noteworthy is Kilwardby's insistence that moral philosophy includes both theoretical and practical components. According to Kilwardby, Aristotle's description of the moral ideal as 'to praktikon' encompasses both practical and theoretical activity:

generally speaking 'operation' includes the act of contemplation properly spoken. Therefore the proposition when he says "omnes sunt opera-

2. Rene-Antoine Gauthier, "Le cours sur l'Ethica nova d'un maître ès Arts de Paris (1235-1240)," Archives d'histoire doctrinale et littéraire du moyen age 42 (1975): 71-141.

3. See P. Osmund Lewry, "Robert Kilwardby's Commentary" where Lewry makes a preliminary study of the similarities in style and content between Kilwardby's known logical works and the commentary on the Ethica vetus and nova. In my capacity as editor of the commentary on the EN, I have continued the comparison and have found further similarities between the work in question and the De ortu scientiarum and Kilwardby's commentary on the Sentences. The edition will appear within the coming year in the Thomas-Institut's (Cologne) G eistegeschichte des $M$ ittelalters: Studien und Texte series.

4. Theodor Köhler, 'Scientia perfecta.' Zur Konzeption philopsophischer Erschließung empirischer Gegenstandsbereiche in 13. Jahrhundert (forthcoming); AnthonyJ. Celano, "Robert Kilward by and the Limits of Moral Science" in Philosophy and the God of Abraham, ed. R. James Long (Toronto, 1991), pp. 31-40. 
trices de operacione communiter" should be understood to extend to the operation of speculation; and similarly the designation 'good' should be extended to the good of speculation and not only to the good of praxis. 5

Kilwardby's interpretation of the meaning of praxis in Aristotle's Ethics, while unusual in the early thirteeenth century, is certainly defensible, because Aristotle clearly intended the activity of contemplation to be included among the operations studied in the practical science of ethics.

Kilwardby's view of the close relationship between practical and theoretical activity leads him to a conclusion that seems astonishing to one familiar with book $X$ of the EN. Kilwardby maintains the superiority of practical activity: "since he [Aristotle] says that the rational soul is twofold, that is, speculative and practical, one must claim that happiness concerns the practical. For praxis is superior to speculation."6 O ne might expect that after the appearance of the entire text of the EN and the corresponding commentaries in Grosseteste's translation (1246-47) that Kilwardby would have modified his understanding of the relation of practical and speculative activities. For Kilwardby, however, physics, metaphysics, mathematics, psychology, and logic have a moral component, since they contribute to an understanding of the human soul. In his De ortu scientiarum Kilwardby argues that all learning is directed to a moral end and that all knowledge is ordered to virtue. As a result, one must consider the final goal of all learning to be moral wisdom. The distinction between theoretical and practical science does not lead Kilwardby to remove ethics from the realm of theoretical wisdom.7 Although he clearly states that ethics "is not for the sake of contemplation alone, like the speculative sciences, for it does not only consider virtue to discover its nature . . . but its purpose is to make us good," Kilwardby does not exclude theoretical considerations from moral science. 8 In order to produce virtuous actions, both intellectual

5. "Communiter autem dicendo operacio comprehendit actum speculandi, racione[ $\mathrm{m}]$ proprie dicta[ $\mathrm{m}]$. Intelligenda est ergo proposicio quando dicit quod omnes sunt operatrices de operacione communiter que se extendit ad operacionem speculacionis; et similiter extendendum est nomen boni ad bonum speculacionis et non solum ad bonum praxis" ( C 285va; $\operatorname{Pr} 1 \mathrm{va)}$.

6. "In prima dicit quod cum anima racionalis duplex sit, scilicet speculativa et practica, ponendum est felicitatem esse circa eam que practica est. Principalior enim est praxis speculacione." (C 290rb; Pr 6rb).

7. "Et ita finis ultimus quodammodo totius philosphiae est ethica moralis (De ortu scientiarum [DOS], ed. Albert Judy, [Toronto, 1976], no. 409, p. 142)." "Quapropter omnis philosophia ad moralem ethicam ordinatur, et ita omnis scientia ad virtutem et beatitudinem" (DOS, no. 648, p. 222). While Thomas Aquinas accepts a similarity in the processes of theoretical and practical reasoning, he distinguishes them because of the uncertain nature of the conclusions of moral reasoning (ST I-II, 94, 4) .

8. "Presens opus non est tantummodo contemplacionis gracia ut sciamus quid est virtus, ibi statum faciendo, sed ut boni fiamus" (C 296ra). 
and practical, one must combine the operations of theory and practice, so that a virtuous person must contemplate about the nature of virtue and the contemplative must live a virtuous life. ${ }^{9}$ While for Aristotle 'contemplative' characterizes an intellectual virtue, which is a component of moral science, for Kilwardby it characterizes both the virtue itself and certain principles within moral philosophy. Kilwardby's reading of the entire text of the EN could only have strengthened his belief that Aristotle intended a close connection between contemplative and moral science in his moral theory. Since Aristotle stressed the importance of contemplative activity for the achievement of moral goodness, Kilwardby concluded that ethics must be, at least partially, a contemplative science. Even though his view of the nature of ethics may have some foundation in Aristotle's writings, Kilwardby's understanding of the nature of moral science and the relative value of speculation and praxis is certainly at odds with Aristotle's intention. For Aristotle contemplation is an important consideration in moral deliberation; it is not a description of the nature of ethics.10

In composing his commentary on the Sentences (c. 1256), Kilwardby is more clearly influenced by the moral theology of Augustine than the ethical deliberations of Aristotle. Still he maintains his position that all human knowledge is directed to a moral end. All knowledge and every deliberation belongs to prudence, but to a prudence that is connected to Aristotle's notion of phronesis only in the widest sense. Kilwardby maintains that the goal of prudence is a disposition to the end of faith, and so the common order of all virtues is a disposition to true beatitude. The ends of the cardinal virtues of justice, temperance, courage, and prudence seem to be mere dispositions to perfect beatitude, just as the cardinal virtues themselves seem to be mere dispositions to the theological virtues.11 Throughout his entire career Kilwardby maintains the position that specu-

9. "Quaero igitur quomodo distinguatur penes speculacionem et praxim, cum illae quae practicae sunt sint etiam speculativae-oportet enim prius virtute speculativa contemplari quod virtute practica debemus operari-et econverso speculativae non sine praxi sunt" (DOS, no. 393, p. 138). "Et dicendum quod omnis operativa scientia aliquid habet de contemplatione et econverso" (DOS, no. 394, p. 138).

10. For further discussion of this topic, see Celano, "Robert Kilwardby."

11. "Aliud enim notabile ex praedictis patet circa has virtutes et suos fines, scilicet quod sicut in via cardinales subser viunt theologicis et ad illas ordinantur, sic earum fines ad fines theologicarum, et hoc in patria. Coniunctio enim cum fine videtur esse quaedam dispositio ad visionem, et ita finis prudentiae disponit ad finem fidei ... . ordo est communis omnium dispositio ad veram beatitudinem, et ita fines virtutum cardinalium dispositiones quaedam videntur ad perfectam beatitudinem, sicut et virtutes cardinales quaedam dispositiones sunt ad theologicas" (Robert Kilwardby, Quaestiones in librum tertium Sententiarum, Teil 2: Tügendlehre, ed. Gerhard Leibold [Bayer. Akad. d. Wissenschaft; Veröff. der Kommission für d. H erausgabe ungedrückter Texte aus d. mittel. Geisteswelt, 12: Munich, 1985] , q. 32, p. 128, II. 108-17). 
lative activity must be included among the moral determinations of the will, even if contemplation considered in itself does not belong to a subordinate science. When Kilwardby considers the effect of the speculative and practical sciences on human beings, however, he considers ethics superior because it concerns the will which can chose between alternatives. In Kilwardby's terms, speculative activities are not subalternate (non subalternentur) to practical philosophy, but they are ordered to ethics insofar as they are at its service.12 Kilwardby expresses the notion of the will's supremacy in Augustinian terms when he claims that even the final cognition of the supreme good is ordered to the love for it and to the operation by which we may attain and enjoy the highest good.13 The mode of expression in De ortu scientiarum is clearly influenced by Augustine's notion of the human desire for union with God, but the basic moral principles were already present in Kilwardby's earlier commentary on the EN.

Although Kilwardby's understanding of the nature of practical science differs from that of Aristotle's, his interpretation of the doctrine of happiness in the EN contributed to a deeper and more proper understanding of the intention of the Philosopher. Kilwardby understands the nature and goal of ethics to be action. Because moral philosophy attempts to influence human actions, it admits more uncertainty in its conclusions than is the case in the theoretical sciences. Kilwardby agrees with Aristotle that the "nature of moral affairs does not permit a wholly certain determination, since they do not come from fixed causes, but from the will."14 The decisions of the will must admit variety and difference, so the moral philosopher must characterize the conclusions of his study to be merely 'typice et grosse'. For Kilwardby and his contemporaries, the differing opinions about human justice and the means (external goods) by which humans attain goodness allow for such diversity that absolute certainty can never be expected in

12. "Sed nec potest subalternari aliis speculativis, quia omnes considerant veritatem quae inest rebus naturalibus secundum quod naturae sunt, et dico modo naturale prout dividitur contra voluntarium. Ethica autem considerat operationem voluntariam virtuosam vel vitiosam. Nunc autem naturale non subalternat sibi voluntarium, quia natura est principium motuum potens tantum uno modo agere, sed voluntas est principium potens agere opposita. Et sicut voluntas est principium nobilius quam natura, sic omnes speculativae ordinantur ad ethicam, non ut ei subalternentur sed ut ei famulentur" (DOS, no. 405, p. 141).

13. "Et inde ulterius summi veri cognitio, quod est causa prima, ordinatur ad amorem eius et ad operationem eius et ad operationem virtute perfectam per quam ipsum summum verum tandem sine aenigmate videamus, et idem summum bonum habeamus et ipso fruamur. Et ita totus finis scientiae speculativae ordinatur ad finem ethicae, et tota speculativa ad ethicam et ei famulatur" (DOS, no. 405, p. 142).

14. "Sed natura rerum moralium non patitur determinacionem omnino (non: C) certam, cum non sint (fuit: $\mathrm{Pr}$ ) ex certis causis, sed a voluntate" (C 286vb; $\mathrm{Pr}$ $2 v b)$. 
moral deliberations. Ethics may be a science, but not of the same type as mathematics or metaphysics. ${ }^{15}$

After completing his analysis of the nature of moral philosophy, Kilwardby addresses its major theme: the definition and meaning of human goodness. According to Kilwardby, the concern of the moral philosopher is to discover the nature of the good life and those operations which best produce it. The good life is best described as happiness, which Aristotle defines succinctly as living and doing well (bene vivere et bene operari). Kilwardby, unlike his contemporaries, restricts ethics to a consideration of a human life and reserves the question of the fate of the separate soul to another inquiry. ${ }^{16} \mathrm{He}$ further criticizes his contemporaries for their false interpretation of Aristotle, whereby they maintained that he denied happiness to living human beings. Misled by the designation of happiness as the perfection of the human being and their awareness of the imperfection of the physical world, they concluded that no one could attain perfection during an earthly life. Kilwardby responds that although no human being can be considered perfectly happy in the sense of unchanging beatitude, one can be thought to attain complete perfection if happiness is understood within the limits of moral speculation. 17

15. "quod amabile est determinare de hiis grosse et typice (C 286vb; Pr 2vb)... . quod determinandum est de isto bono (de bono et iusto: $\mathrm{Pr}$ ) modo grosso typico, et evidenti per duas raciones. Quarum prima talis: que magnam habent diversitatem in cognoscendo et errorem adquirendo debent determinari modo grosso et evidenti; (per ... . evidenti om. Pr) sed utilia et iusta de quibus consistit civilis sciencia sunt huiusmodi; ergo determinari debet de eis modo grosso et evidenti. . . . Secundo determinat eam per effectum, dicens quod multis contingit pericula ( particula: C) propter differenciam quam habent in cognoscendo bonum et propter errorem quem habent in adquirendo. Quidem enim perierunt propter divicias... " ( C 286vb; Pr 2vb). "Quod hoc quod ostend it Aristotiles scientiam esse de universalibus, ostendit de scientia demonstrativa, et ideo illud pertinet ad speculativam partem philosophiae quae habet demonstrationem facere et demonstrative probare, et non ad activam quia ipsa non habet demonstrative probare aliquid ut doceat Aristoteles in Ethicis" (DOS, no. 381, p. 134). Cf. Thomas Aquinas, Sententia libri Ethicorum, ed. Rene-Antoine Gauthier Opera omnia 47, 1 (Rome, 1969), p. 11, II. 1-47.

16. "philosophi loquentes de felicitate posuerunt eam (om. C) esse vitam aliquam bonam et operacionem bonam, quia dixerunt eam esse idem quod bene vivere et bene operari" ( C 290vb; Pr. 7ra). "Item ethica considerat humanas operationes et voluntates, non dico separatas, sed quas homo gerit in corpore mortali. $\mathrm{H}$ aec autem considerare proprie non pertinet ad metaphysicum, quia ipse considerat spiritus separatos et physicus coniunctos secundum quod coniuncti sunt, sed solum quoad naturam eorum" (DOS, no. 404, p. 141).

17. "Et notandum diligenter quod vocat hic Aristotiles viventes vere bonos, quia si non est vere bonus nisi simpliciter felix, et secundum ipsum aliqui viventes sunt vere boni, secundum ipsum aliqui viventes sunt felices simpliciter; quod est contra eos qui dicunt Aristotilem viventem nolle (velle viventem: C) felicitari nisi incomplete" (C 293ra; Pr 9rb). "N ota ergo quod cum in precedenti parte narraverit Aristotiles felicitatem esse circa opinionem anime studiose practice in vita perfecta, 
A widely circulated corruption of the text of the Ethica nova led most of the pre-1250 commentators to view the Aristotelian concept of happiness as preparatory to the Christain ideal of beatitude. After considering the effect of external goods and misfortunes on the quality of a human life, Aristotle concluded that men can indeed be called blessed, but only as human beings. Aristotle's implied comparison between human happiness and the perfect life of the gods was lost in the corruption of the Greek text. Instead of the proper reading 'beatos ut homines', many versions showed the variant, 'beatos ut angelos'. 18 The corruption of the text led Kilwardby's contemporaries to believe that even Aristotle stressed the imperfect nature of the happiness described by the philosophers. If Aristotle were to maintain a notion of angelic beatitude whereby purely intellectual beings enjoy a perfect union with the supreme being, then the earliest Latin commentators on the EN felt justified in distinguishing between imperfect happiness and perfect beatitude.19 Despite his own reading of the text as 'beatos ut angelos' Kilwardby argues that Aristotle intended to treat only the human good which is attained in this life. Kilwardby understands the phrase 'blessed as angels' as a reference only to Aristotle's comparison between two orders of being and their respective perfections:

And he adds how we call them blessed as angels; and this should not be understood to mean that living men are immortal like angels, but that they are perfect in their own order, just as angels in their own order. 20

The limits of moral science do not permit an inquiry into the fate of the separate soul. Kilwardby leaves open the question whether Aristotle claims any possibility for happiness after death:

iam in subsequenti parte idem declaravit (declaracionis: C) sub alio (aliquod tamen: C Pr) modo. Declaravit enim quod sit circa operaciones ipsius anime optimas et delectibilissimas; et talis est ( eciam: C) operacio practica studiosa durans in vita perfecta" (C 291vb; Pr 7vb). See also Celano, "Robert Kilwardby," pp. 38-39.

18. Ethica Nicomachea, Ethica nova, ed. Rene-Antoine Gauthier, A ristoteles L atinus (Leiden, Brussels, 1972), XXVI, 1-3, fasc. 2, p. 88, I. 14. Gauthier brackets the corruption 'ut angelos'.

19. See, for example, the anonymous examination guide from this period: "est autem alia vita, qua vivit anima in se intelligendo et affectando primum et in tali est felicitas. Anima maxime vivit in se post mortem, cum sit a corpore separata, et ideo innuit hic Aristotiles felicitatem esse post mortem" (Ms Barcelona, Ripoll, 109, f. 136ra). See Claude LaFleur, and Joanne Carrier, L'enseignment de la philosophie au XIIIe siecle: autour du Guide de l'etudiant du ms. Ripoll 109 ... . (Studia artistarum, 5: Turnhout; Brepols, 1997).

20. "Et addit qualiter dicemus eos beatos, ut angelos; et hoc sic intelligendum est non quia homines viventes inmortales sint sicut angeli, sed quia perfecti sunt in ordine suo, sicut angeli in ordine suo" (C 293va; Pr 9vb). 
Thus he perhaps does not consider happiness other than that which is called the life according to the limit of civic doctrine. And perhaps civic doctrine should not consider another happiness. Whether after death the soul is made happy or the whole human being is may not be relevant to it ( civic doctrine), and Aristotle does not determine this. ${ }^{21}$

Kilwardby is equally careful in his formulation of his response to the question of the cause of happiness. Unlike his contemporaries who concluded that only God can cause the intellectual union between Himself and man and thereby produce happiness, Kilwardby argues that Aristotle's more limited vision of human perfection allows one to assert the human role in the achievement of the human good.22

Kilwardby's reluctance to determine the questions of the fate of the soul after death and the divine causality of human goodness foreshadows the responses of his more famous confrères, Albert the Great and Thomas Aquinas. Albert argues that the moral human good can result only from the soul's acts, but divine influence must be taken into an account of anyexplanation of causality. Albert concludes that human operationsare the propinqua causa fe licitatis and that God works with the mediation of proximate causes to bring about human happiness. Thomas's response is similar to Albert's in that he claimsthat it istolerable (tolerabiliter) to assume that happiness proceedsfrom human actions, since man cooperates with God in the attainment of his own goodness(homo aliquid cooperatur). Both Albert and Thomassee Aristotle's description of the limits of human happiness not as rejection of the Christian ideal of eternal beatitude, but rather as a desire to focusupon the specifically human actions that constitute the aim of moral actions. 23

Kilwardby's final contribution to the understanding of the EN in the thirteenth century was his recognition of the identity of the Greek term 'phronesis' with the Latin virtue of 'prudentia'. Earlier masters of the Parisian

21. "Unde forte non intendit de alia (illa: C) felicitate nisi que dicitur vita secundum modum (iussus: $\mathrm{C}$ ) doctrine civilis. $\mathrm{Nec}$ debuit forte doctrina civilis de felicitate alia pertractari (perscrutari: C). Utrum enim post mortem felicitetur anima vel totus homo forte non pertinet ad ipsam, nec hoc determinat Aristotiles" (C293va; Pr. 9vb). "Utrum autem mortuus felicitetur vel non, neque asserit neque deasserit"( C 293vb; Pr 10va).

22. "si felicitas non sit a deo penitus immissa, sed propter quamdam virtutem, sic aut disciplinam, aut assuetudinem . . . ergo felicitas est finis et bravium virtutis; et ita videtur quod ipsa habetur propter virtutem" ( C 291vb; Pr 7vb). “. . . dicit quod cum (om. C) quicquid inest (om. C) hominibus insit a doctrina, racionale est felicitatem a deo datam esse, cum deus sit causarum optima et felicitas sit bonorum humanorum optimum; sed utrum sic sit vel (om. C) non alterius scrutacionis est quam civilis, sicut forte methaphisice vel theologie." Kilwardby rejects the position of the Pseudo-Pecham who argues that happiness must be caused by God: "felicitas est a prima causa" ( Ms. Florence Naz. conv. soppr. G 4.853, ff. 18vb-19ra).

23. See Anthony Celano, "The Understanding of the Concept of Felicitas in the pre-1920 Commentaries on the Ethica N icomachea," M edioero, 12( 1986) , pp. 48-49. 
Arts faculty, such as Arnoul of Provence, understood phronesis to be a supreme mystical virtue whereby the human soul achieves the highest degree of contemplation of God. He thought prudence, however, to be a distinct virtue of a lower rational faculty whose main function is the habitual governance of the passions. ${ }^{24}$ Kilwardby is the first medieval commentator on the EN to define phronesis as a type of prudence through which one choses what is previously recognized and desired. 25

Kilwardby's successful delineation of the realms of Christian moral belief and the newly discovered treatment of human goodness in Aristotle's EN does not lead him to a complete understanding of the exact nature and constitution of Aristotelian eudaimonia. Kilwardby is never able to explain adequately the relationship between human virtue and happiness. In his commentary on the EN Kilwardby vacillates between the idea that happiness consists in virtuous actions and the notion that virtue is merely a subordinate mean s to happiness. Kilwardby accepts Aristotle's main intention to be the description of that human good which is attained through action: "It should be noted that he [Aristotle] says that this good is an operable good, as he intends that a human being can achieve it through his own operations." 26 Kilwardby's recognition of the supreme human good of all human actions as 'operable' does not direct him to a very clear description of its nature. O nly once in his commentar y does Kilwardby attempt to specify the elements of human happiness:

but those who said that happiness is simply virtue or some species of it, are closer to the truth than others, because happiness is an action (actio) of the soul according to virtue [truth, $\mathrm{C} \mathrm{Pr]} \mathrm{or} \mathrm{the} \mathrm{action}$ according to which happiness consists is characterized by virtue itself. 27

The preceding statement is as close as Kilwardby comes to identifying human virtuous acts with happiness. He soon retreats to the more common position of his contemporaries who viewed human virtues merely as a means to the supreme human good. While Kilwardby does not comprehend Aristotle's notion of eudaimonia to be the same as Christian beatitude, he

24. See Rene-Antoine Gauthier, "Arnoul de Provence et la doctrine de la fronesis, vertue mystique suprême," Revue du moyen âge latin 19 (1963): 139.

25. "Per fronesim, que prudencia quedam est, electionem prius cognitorum et amatorum ( C 295ra). Similiter et fronesis cum sit prudencia in eligendo prius cognita et amata" ( C 295rb). See AnthonyJ. Celano, "The End of Practical Wisdom: Ethics as Science in the Thirteenth Century," Journal of the H istory of Philosophy 33 (1995): 229-33.

26. "Et notandum quod dicit illud bonum esse bonum operabile, tamquam velit quod homo posset consequi istud per suas operaciones" (C 289va; Pr 5va).

27. "Sed qui dixerunt felicitatem esse virtutem simpliciter, aut aliquam (ad quam: C) speciem eius, magis concordant (concedant: C) veritati quam alii, eo quod felicitas est actio anime secundum virtutem (veritatem: C Pr), sive actio secundum quam consistit felicitas est ipsius virtutis" ( C 291ra; Pr 7va). 
has great difficulty in perceiving the way in which virtue can be a constitutive element of happiness. Because he divorces virtue from happiness, Kilwardby can only describe happiness as a universal general goal, void of content, almost as a formal concept that unifies abstractly Aristotle's moral theory. The human good, he explains, is twofold: "the highest good or felicitas; and the lower good ordered to the highest, namely virtue."28

Kilwardby's usual interpretation of the supreme human good separates sharply the goal of all actions, happiness, from the operations themselves. As he explains Aristotle's doctrine, once virtue is understood by the moral philosopher then he can more easily comprehend the goal of his study, which is happiness. ${ }^{29}$ Kilwardby argues that a virtuous man can only be called happy in the sense that a man is called healthy when he is taking medicine. Just as the patient employs medicine as a means to regain health, the virtuous person uses his virtuous acts as a means to secure happiness. 30

Aristotle's description of happiness as a perfect continuous act and the medieval awareness of the imperfect nature of all human achievement, including happiness, create a dilemma in Kilwardby's moral philosophy. Kilwardby's difficulty arises in his mistaken reading of Aristotle's description of perfection as the defining quality of happiness. Since the human good is characterized by continuity and perfection, and since virtue can be neither continuous nor perfect, Kilwardby concludes that happiness cannot possibly consist in virtue. 31 Kilwardby concludes that virtue can only be an inferior good, which disposes one to happiness. All virtues, both intellectual and moral, are understood hierarchically so that each type of virtue directs

28. "Determinato de summo bono quod est felicitas, hic intendit de bono inferiori ordinato ad ipsum quod est virtus" (C 294rb; Pr f. 10va).

29. "Primo dicit quod de virtute scrutandum est, quia facilius erit contemplari determinata circa felicitatem per cognicionem virtutis. . . . Ex hoc patet quod cognita virtute, facilius erit contemplari felicitatem" (C 294rb; $\operatorname{Pr} 10 \mathrm{va}$ ).

30. "Addit quod virtuosus non est dicendus felix, nisi sicut dicitur sanus qui utitur pocione; sicut enim hic est in via (una: C) ad sanitatem, sic virtuosus est in via ad felicitatem" (C 288rb; Pr 4rb).

31. "Ostendit ipsam $<$ virtutem $>$ non esse felicitatem per duas raciones, quarum prima talis est: virtus est in imperfectis; felicitas non est in eis; ergo etc. Secundo declarat, dicens quod virtuousi non secedere et dormire et non operari in vita, quamvisscilicet possint operari et non impediantur. Iste autem condiciones ( consideraciones: C) sunt imperfectorum; quare habentes virtutem possunt esse imperfecti ... virtuosi paciuntur mala et multa infortunia; sed felicitati non compatitur mala vel infortunia; ergo virtus non est felicitas" (C 288ra; $\mathrm{Pr} 4 \mathrm{rb}$ ).

32. See above, nn. 28 and 31. "Per virtutes intellectuales intelliguntur virtutes quibus homo ordinate se habet ad suum creatorem. Et hoc consistit circam partem principaliter et secundum se racionale absolute; per morales intelliguntur virtutes (om. C) que bene ordinant hominem ad hec inferiora, et consistunt circa eandem partem racionalem in comparacione ad sensitivam" (C 295rb; Pr 11va). "Virtus autem (om. C) intellectualis aut consistit in cognoscendo primum et sic est intelligencia (intellectiva $\mathrm{C}$ ); et sic sapiencia aut in electione et participacione aliqua ipsius cogniti et amati (amici C)" (C 295rb; Pr 11va). 
a human being towards a proper relationship with the Creator. 32 The strict adherence to the medieval doctrine of the unity of the end obscures Kilwardby's recognition of the nature of Aristotelian happiness. Despite his own awareness of how the term 'perfect' may be applied in a restricted sense (note 20), Kilwardby's view of virtue as relevant only to imperfect beings leads him ultimately to exclude it from the definition of happiness. The activity of virtue, which is essential to Aristotle's notion of eudaimonia, remains a subordinate good in Kilwardby's and his contemporaries' commentaries. The reader of Kilwardby's commentary is left wondering just what Kilwardby thought felicitas to be, since virtue can only be a means to happiness, while the perfect union with God, which is the Christian moral goal of beatitude, lies beyond Aristotle's scope of inquiry. So neither virtuous acts nor a spiritual union can fulfill the requirements for happiness.

Kilwardby's interests changed after his theological studies at Oxford, but his views on the function of human virtue in the production of human goodness remained constant. From the time of his De ortu scientiarum (c. 1250) Kilwardby devoted more attention to theological issues, but retained a special interest in the relationship between ethics and moral theology. In his analysis of the contributions of the moral philosophers, Kilwardby displays his obvious preference for the moral teachings of Augustine, despite retaining positions reminiscent of his earlier ideas of the commentary on the EN. H is criticism of moral philosophy is directed not at the falsity of the philosophers' conclusions, but rather at their inadequacy:

\begin{abstract}
although the philosophers did not reach the ultimate end of the spiritual good so that they might have discovered that the supreme human good is the fruition of God, and were content with a virtue that was a means to that end, nevertheless they did not wholly err, since they posited a perfect virtue and a perfect act according to virtue. H abitual virtue and its act is a great part of the human perfection in this life, which nevertheless leads further, and is a disposition to another virtue and more perfect life and should be totally ordered to it. The philosophers' doctrine of virtue, while not false, is insufficient, and therefore is not without use to Catholics. 33
\end{abstract}

33. "Et quamvis philosophi non pervenirent ad ultimum finem boni spiritualis ut invenirent Dei fruitionem esse summum bonum humanum, sed steterint in virtute quae est ad illum finem, non tamen omni modo erraverunt ponentes virtutem perfectam et actum perfectum secundum virtutem, dico consuetudinalem, esse humanam perfectionem. Virtus enim consuetudinal is et actus eius magna pars est perfectionis humanae in hac vita, quae tamen ulterius ducit, et est dispositio ad aliam virtutem et perfectiorem vitam, et ad illam omnino ordinanda. Philosophorum igitur doctrina de virtute quoad hoc falsa non erat sed diminuta, et ideo non inutilis est catholicis quibus Deus misericorditer plenam de beatitudine ostendit veritatem" (DOS, no. 353, p. 125). On Kilwardby's use of Augustine and Aristotle, see Johannes Schneider's intro. to Quaestiones in librum primum Sententiarum (Bayer. Akad. der Wiss., Veröff. der Komm. für die H erausgabe ungedrückter Texte aus der mittelalt. Geisteswelt, 13; Munich, 1986), pp. 55*-56*. 
Although Kilwardby admits that moral virtue is a significant element in human perfection, he quickly returns to the curious hierarchical moral view sketched in his commentary. All human knowledge is directed to the moral end: the habitual virtues contribute to the intellectual, the primary of which are the four cardinal virtues of prudence, courage, justice, and temperance. These four virtues lead to the three theological virtues of faith, hope, and charity, which ultimately lead to eternal beatitude. Aristotle's primary virtue of prudence loses its dominant role in the moral theology of Robert Kilwardby. 34 According to Kilwardby, the significant contribution of moral virtues to human goodness is their purgative nature. Rather than constitute human perfection, all human virtues, including prudence, prepare the mind to receive and enjoy ultimate goodness. In Kilwardby's hierarchy of moral achievement, however, there seems to be no place for felicitas itself. It has no independent existence, no reality other than the general description of living and doing well. The intimate connection between virtue and happiness that characterizes Aristotle'smoral writingsiscuriouslyabsent in the works of Kilwardby. Always seeking to define human actions in light of the Christian ideal of perfect beatitude, Kilwardby omits a description of the constitution of human happiness. To him the function of all human achievements is to prepare or dispose the human soul for the reception of absolute perfection:

there is a common disposition of all < virtues $>$ to true beatitude, and so the ends of cardinal virtues seem to be certain dispositions to perfect beatitude, just as the cardinal virtues are certain dispositions to the theological ones. 35

In his ordering of virtue to a higher good, Kilwardby is remarkably consistent from the time of his earliest works at Paris until his final theological treatises as a member of the Dominican order.

If prudence is the supreme moral virtue in Aristotle's Ethics, charity replaces it in Kilwardby's moral theology. For Kilwardby, Aristotle's attempt to define the moral life (recte vivendi) and the virtues that lead to it can be reduced to one Christian virtue, charity. Charity, Kilwardby maintains, contains in itself the practice of all other virtues. 36 The dictates of charity

34. In III Sent. q. 32, p. 128, II. 108-13. See also q. 27, p. 103, II. 191-96. On the purgative role of virtue: " $\mathrm{H}$ arum virtutum distinctio secundum Plotinum et Macrobium videtur sic sumi: virtus aut est exemplaris et haec est in Deo, aut exemplata et haec in creatura, et haec est ut in statu proelantis aut in triumphantis. Si proelantis, aut contra peccata vitae communis et sic politicae, aut contra peccata vitae solitariae et sic purgatoriae. Si autem ut in statu triumphantis, sic sunt virtutes purgati animi" (In III Sent. q. 31, p. 123, II. 252-57). On the influence of Augustine see In III Sent. q. 31, pp. 123-24, II. 258-69.

35. In III Sent. q. 32, p. 128, II. 113-18.

36. "Ergo qui conformatur secundum affectum totali arti generali recte vivendi, habet habitus omnium virtutum. Sed qui habet caritatem, conformatur secundum 
reduce the complicated, and ultimately unsatisfactory, ethics of the philosophers to four simple rules, which seem to Kilwardby to represent a far more satisfactory moral doctrine than that of Aristotle: "(1) Love that which is good and only good; (2) despise that which is evil and only that; (3) (derived from the first) not all good is to be loved equally, but something should be loved according to the degree and order of its goodness; (4) (derived from the second) not all evil should be equally despised, but something should be despised according to the degree of its evil." 37

Kilwardby's logical training continued to exert influence on his moral theology to the end of his literary career. The desire to classify each element and choice in a human life led Kilwardby to construct a moral hierarchy in which every act is judged according to its contribution to the final end. In his commentary on the EN, the distinction between the simply supreme uncreated good, which is God, and the created good, or moral virtues, did not result in an autonomous moral philosophy.38 Kilwardby views all human science and action to be directed toward a moral end, but that end is best described in the moral teachings of the Church. Despite his important contributions to the receptions of Aristotle in the thirteenth century, Kilwardby's commentary is ultimately unsatisfactory, because he is unable to explain adequately the relation between virtue and happiness. His incomplete understanding of Aristotle's doctrine of the supreme moral good is quickly rendered obsolete by the commentaries of his more famous Dominican confrères, Albert the Great and Thomas Aquinas. But Kilwardby's commentary represents an important transitional phase in the medieval understanding of Aristotle's moral doctrine. His awareness of the limitations of the nature and goal of the EN, his philosophical definition of the human good as bene vivere et bene operari, and his careful exposition of the cause of happiness prepared the way for the more sophisticated responses of later commentators. If his moral philosophy may seem inadequate to the modern reader, Kilwardby might have re-

affectum totali arti generali recte vivendi. Ergo qui habet caritatem, habet habitus omnium virtutum" (In III Sent. q. 27, p. 102, II. 135-38). "Quod habens caritatem, habet habitualiter politicas virtutes" (In III Sent. q. 27, p. 104, II. 205-6).

37. "Ars incommutabilis recte vivendi continet in se qusasdam regulas rectae vitae, quae sunt communes animi conceptiones omni menti. Unde et sunt in naturali notitia cuiuslibet hominis, et in illis continetur notitia vivendi secundum omnes virtutes sufficienter. Et sunt regulae quattor quarum duae sunt principales et duae consequentes ex illis, et de principalibus secunda sequitur ex prima. Prima talis est: Bonum amandum est et solum. Secunda talis: Malum odiendum est et solum. Tertia sequitur ex prima, scilicet quod non omne bonum est aequaliter diligendum sed quodlibet secundum gradum et ordinem suae bonitatis. Quarta sequitur ex secunda, scilicet quod non omne malum est aequaliter odiendum, sed quodlibet secundum gradum suae malitiae" (In III Sent. q. 27, p. 102, II. 143-52).

38. "Ipsa enim loquendo de summo bono simpliciter <increato> est vera; loquendo autem de summo bono quod est creatum de quo intendit hic Aristotiles, non est vera" (C 287rb-287va; Pr 3va). 


\section{ANTHONY J. CELANO}

sponded that moral philosophy itself is unsatisfactory, especially in comparison to the simple moral doctrine of Christianity. After his entry into the Dominican order, Kilwardby seemed less concerned with the course of moral philosophy and more involved with the description of the best possible method for attaining knowledge of God. Even his participation in the condemnations of Oxford in $\mathbf{1 2 7 7}$ may be viewed not as a hostile reaction to the conclusions of human reason, but rather as an expression of his desire, perhaps naive, to preserve the truths of faith from the increasingly complex and conflicting claims of philosophy itself. 39

39. Daniel A. Callus, The Condemnations of St. Thomas at Oxford (Blackfriars; Oxford, 1955). 